\title{
Kemandirian dan Kedisplinan Anak yang Diasuh oleh Orangtua Pengganti
}

\author{
Yasinta Maria Fono $^{1 凶}$, Lara Fridani ${ }^{2}$, Sri Martini Meilani ${ }^{3}$ \\ Pendidikan Anak Usia Dini, Universitas Negeri Jakarta
}

\begin{abstract}
Abstrak:
Penelitian ini bertujuan untuk mencermati kemandirian dan kedisplinan anak usia 4-6 tahun yang diasuh oleh orangtua pengganti. Subyek penelitian adalah kakek dan nenek yang berperan sebagai orangtua pengganti. Metode penelitian yang digunakan adalah penelitian kualitatif dengan pendekatan studi kasus. Pengumpulan data dilakukan dengan cara observasi, wawancara, dokumentasi dan hasil catatan lapangan. Teknik analisis data yang digunakan adalah model Campbell. Pemeriksaan keabsahan data dilakukan dengan perpanjangan keikutsertaan, ketekunan pengamatan dan triangulasi. Temuan hasil penelitian menunjukkan bahwa kemandirian dan kedisplinan pada anak usia 4-6 tahun di dibentuk oleh pola pengasuhan orangtua pengganti. Orangtua pengganti menanamkan sikap mandiri kepada anak membiarkan anak melakukan aktivitas sehari-harinya sendiri seperti makan, mandi, me rapihkan tempat tidur, memakai seragam, memakai sepatu dan kesekolahpun sendiri. Kesimpulannya bahwa anak yang mandiri dan disiplin tidak bisa terbentuk sendiri atau tidak terjadi begitu saja tanpa adanya stimulasi dari orangtua.
\end{abstract}

Kata kunci : kemandirian; kedisplinan; anak usia dini; parenting, orangtua pengganti

\begin{abstract}
This study aims to examine the independence and discipline in child aged 4-6 years who is taken care by substitute parental. The research method used is qualitative research with case study approach. Data collection is done by observation, interview, documentation and results of field notes. The data analysis technique used is Campbell model. Examination of the validity of the data is done with the extension of participation, persistence observation, and triangulation. The findings research indicated that child's independence and discipline aged 46 year are formed by the parenting pattern of substitute parental. Substitute parental inculcate the child's independence and dsicpline by let the child do the daily activities alone such as eating, bathing, making the bed, wearing uniform, and wearing shoes. The conclusion is that an child's independent and discipline can not be formed alone or did not just happen in the absence of stimulation of a parents.
\end{abstract}

Keywords : independence; discipline; early childhood; substitute parental; grandparents

Copyright (c) 2019 Yasinta Maria Fono, Lara Fridani, Sri Martini Meilani

$\triangle$ Corresponding author:

Address : Jalan Pemuda, Rawamangun, Pulogadung, Jakarta

Email : yasintamariafono@gmail.com

ISSN 2356-1327 (Media Cetak)

ISSN 2549-8959 (Media Online) 
538 Kemandirian dan Kedisplinan Anak yang Diasuh Oleh Orangtua Pengganti

\section{PENDAHULUAN}

Anak usia dini merupakan salah satu modal dasar yang sangat berharga untuk menghasilkan sumber daya manusia yang berkualitas. Oleh karena itu, perlu dipersiapkan sejak dalam kandungan agar kelak menjadi sumber daya manusia yang berkualitas, sehat, bermoral, dan berguna bagi masyarakat melalui pengasuhan yang baik (Hasnida, 2015). Anak-anak adalah generasi penerus bangsa, merekalah yang kelak membangun bangsa Indonesia menjadi bangsa maju, yang tidak tertinggal dari bangsa-bangsa lain. Dengan kata lain, masa depan bangsa ditentukan oleh pengasuhan dan pendidikan yang diberikan kepada anak sebagai generasi bangsa.

Anak usia dini sering disebut sebagai masa golden age karena anak-anak mengalami pertumbunhan dan perkembangan yang pesat pada masa ini. Santrock, (2011) mengatakan bahwa anak usia 4-6 tahun perkembangan otak hampir seperti orang dewasa. Hal tersebut berpengaruh dalam merespon berbagai informasi dari lingkungan. Masa ini merupakan masa yang paling tepat untuk melakukan pengembangan kemampuan fisik, bahasa, social-emosional, konsep diri, seni moral dan nilai-nilai agama serta kemandirian pada anak (Wiyani, 2012).

Sujiono, (2009) mengatakan bahwa masa ini adalah periode sensititif (sensitive periods), selama masa inilah anak secara khusus mudah menerima stimulus-stimulus dari lingkungannya. Pada masa ini, anak siap melakukan berbagai kegiatan dalam rangka memahami dan menguasai lingkungannya. Selanjutnya Montessori menyatakan bahwa usia keemasan merupakan masa di mana anak mulai peka untuk menerima berbagai stimulus dan berbagai upaya pendidikan dari lingkungannya baik disengaja maupun tidak disengaja. Masa anak usia dini merupakan masa yang menuntut perhatian ekstra dari orangtua.

Orangtua merupakan penyedia utama pengasuhan anak dan strategi, relasi dan interaksi mereka akan berdampak pada aspek perkembangan anak (Desai, Reece, dan Shakespeare-Pellington, 2017). Artinya bahwa perkembangan anak tergantung pada kualitas pengasuh dari lingkungan. Mereka akan bertumbuh dan berkembang dengan baik dibawah kondisi pengasuhan yang optimal. Orang tua yang memiliki komitmen terhadap kesejahteraan anaknya dapat memiliki pengaruh yang sangat positif. Anak yang tinggal dengan ayah ibu akan lebih baik dibandingkan anak yang hanya tinggal dengan ibu saja,atau hanya ayah saja maupun tinggal denga pengasuh lainnya. Hal ini dikarenakan ayah dan ibu memiliki perannya masing-masing dalam mengasuh anak. Mengasuh anak tidak hanya dibebankan kepada tanggung jawab seorang ibu namun ayah dan ibu bersamasama dalam mengasuh anak (Tegariyani \& Santoso, 2018).

Pengasuhan orangtua akan lebih baik karena orangtua lebih mengetahui dan memahami tumbuh kembang anak, sehingga orangtua bisa mengasuh dan mendidik anak sesuai dengan tahap perkembangan anak. Pengasuhan yang baik adalah pengasuhan yang dilakukan oleh kedua orangtua dengan menanamkan nilainilai kehidupan pada anak (Sherr, Roberts, Hothi, \& Balchin, 2018). Kasmadi, (2013) mengatakan bahwa yang dimaksud dengan nilai adalah nilai moral dan non moral. Penanaman nilai-nilai moral yang sifatnya untuk diri sendiri maupun sosial dirinci pada sikap dan perilaku seperti jujur, toleran, perilaku disiplin, kerjasama, mandiri, dan sebaginya. Margaretha, Kurniah, Dharmayana, Sasongko, \& Lutfi, (2018) dalam penelitian mengatakan bahwa pengasuhan orangtua sangat penting dalam membentuk kemandirian anak, orangtua 
harus lebih membuka pikiran dalam bersosialisasi, dekat dengan anak sebagai seorang sahabat dan memperhatikan segala kebutuhan anak, sehingga anak merasa dipenuhi dan di perhatikan oleh orangtua, dihargai dan menyenangkan. Orangtua harus lebih melindungi dan merupakan model kemandirian bagi anak dalam memecahkan masalah sesuai dengan kemampuan anak sehingga anak mempunyai potensi menjadi seseorang yang mandiri.

Hal ini senada dengan hasil penelitian yang dilakukan oleh (Suparmi, Ekowarni, Adiyanti, \& Helmi, (2018) mengatakan bahwa pengasuhan orangtua terbukti menjadi mediator dalam mempengaruhi dan menanamkan kemandirian pada anak. Kemandirian pada anak tidak terjadi begitu saja melainkan ada stimulus dari pengasuhan dan orangtua maupun orangorang yang berada di sekitar anak. Hasil penelitian oleh (Froiland, 2013) mengungkapkan bahwa orangtua seharusnya mengaplikasikan teknik pola asuh dengan mendukung kemandirian anak di lingkungan rumah. Orangtua bersedia memberikan contoh dan teladan tentang bagaimana mendukung kemandirian yang mana dapat digeneralisasikan untuk belajar dalam berbagai bidang kehidupan.

Selain mempengaruhi kemandirian, pola asuh orangtua juga mempengaruhi kedisiplinan anak. Pola asuh orang tua adalah bagaimana cara orangtua dalam menanamkan kedisiplinan anak (Hasbullah, 2012). Posisi keluarga sangatlah penting dalam menentukan tingkat disiplin pada diri anak. Alberto, Cuervo, and Nieblas (2018) dalam penelitianya menyatakan bahwa Posisi keluarga dan iklim keluarga sangatlah penting dalam menentukan tingkat kedisiplinan pada diri anak. Alaazi, D. A., Salami, B., Yohani, S., Vallianatos, H., Okeke-ihejirika, P.,dan Nsaliwa, C. (2018) dalam penelitiannya mengatakan bahwa disiplin merupakan pengaruh yang dirancang oleh orangtua untuk membantu anak agar mampu menghadapi tuntutan dari lingkungan dengan tujuan dari disiplin anak adalah untuk menanamkan perilaku, nilai-nilai, dan budaya yang dapat diterima, keluarga dan individu, dengan perbedaan yang sering di ambil antara metode disiplin fisik dan non fisik. Penanaman perilaku disiplin ini akan terjadi melalui pengasuhan yang baik dari orangtua kepada anaknya.

Kampung Hobobelu terletak di Desa Ekoroka Kecamatan Golewa Kabupaten Ngada Propinsi NTT. Mayoritas pekerjaan yang di geluti masyarakat di kampung ini adalah petani. Masyarakat Hobobelu bekerja keras demi memenuhi kebutuhan hidup sehari-hari. Orangtua di kampung ini lebih banyak sibuk dengan bekerja di kebun dan bahkan ada yang pergi bekerja di luar negeri (migrant worker) sehingga tidak terlibat langsung dalam mengasuh anak.

Hasil wawancara dengan beberapa orangtua, dan tokoh masyarakat setempat ditemukan bahwa banyak orangtua baik ayah maupun ibu yang ada di kampung ini menganggap bahwa tanggung jawab terbesar dalam pengasuhan adalah dengan memenuhi kebutuhan dan memberi fasilitas yang cukup bagi anak, sehingga yang lakukan oleh orangtua adalah mencukupi segala kebutuhan mereka dengan bekerja sepanjang hari atau bekerja di luar negeri (migrant worker) sehingga menyerahkan pengasuhan kepada keluarga terdekat.

Observasi awal peneliti dilokasi, ditemukan beberapa keluarga dikampung tersebut pergi bekerja diluar negeri (migrant worker) sehingga pengasuhan anak dilimpahkan kepada keluarga terdekat, ada yang di asuh oleh paman dan bibi, kakek dan nenek serta kerabat dekat lainnya yang orangtua percaya. Dari hasil observasi dan wawancara, peneliti memilih satu anak yang diasuh oleh kakek dan 
nenek yang mana memiliki karakteristik yang berbeda dengan yang lainnya. Perbedaan sikap yang menonjol yaitu anak yang di asuh oleh orangtua pengganti (grandparents) lebih terlihat mandiri dan disiplin dibandingkan dengan anak yang diasuh oleh orangtua sendiri, maupun paman dan atau bibi. Hal ini ,berbeda dengan hasil penelitian yang dilakukan oleh (Edwards, 2018), bahwa anak yang diasuh oleh orangtua pengganti (grandparents), memiliki sikap yang negatif dibandingkan dengan anak yang tinggal bersama dengan kedua orangtua.

Pengasuhan anak yang dilakukan oleh orangtua pengganti (grandparents) yang diakibatkan orangtua bekerja diluar negeri (migran worker) demi mencukupi kebutuhan keluarga. Sehingga yang terjadi adalah pengasuhan anak sepenuhnya dilimpahkan kepada kakek dan nenek. Ada orangtua yang meninggalkan anaknya dibawah asuhan kakek dan nenek sejak anak berumur tiga tahun. Orangtua pergi bekerja ke luar negeri sebagai pekerja imigran bukan dengan sengaja meninggalkan tanggungjawab, akan tetapi karena tuntutan kebutuhan ekonomi yang harus dipenuhi. Kakek dan nenek yang sudah tua harus membagi waktu untuk mengasuh anak dan juga harus bekerja di ladang demi kehidupan sehari-hari. Namun hal ini, tidak membuat kakek dan nenek merasa lelah tapi mereka merasa ada kebahagiaan tersendiri karena, kehadiran cucu di rumah membuat mereka merasa terhibur dan terbantu. Dalam hidup keseharian, kakek dan nenek membiarkan anak untuk melakukan pekerjaan-pekerjan yang ringan seperti menyapu halaman rumah, cuci piring, dan kadang pergi menemani neneknya untuk untuk mencari kayu api di hutan.

Dari hasil wawancara dengan bapak MR dan mama LD, ditemukan bahwa dalam mengasuh anak kakek dan nenek tidak pernah bersikap manja pada anak melainkan dilakukan dengan tegas dan proporsional. Tegas disini bukan mengekang ruang gerak anak, tetapi tegas disini untuk mengatur anak agar disiplin dan bisa bertanggungjawab terhadap orangtua dan dirinya sendiri. Pengasuhan orangtua pengganti (grandparents) tidak terlepas dari pandangan hidup wilayah dan budaya setempat dimana menurut orangtua pengganti (grandparents) bahwa mengasuh dengan mempertahankan dengan pola-pola lama justru membuat anak lebih berhasil. Sejalan dengan pendapat Santrock bahwa pengasuhan dapat dipengaruhi budaya, etnisitas, dan status sosial ekonomi. Budaya memiliki nilai-nilai yang digunakan sebagai tolok ukur yang menentukan baikburuk, boleh-tidak boleh, benar-salah dalam ekspresi perilaku anak (Fitria, 2016).

Breheny, Stephens, \& Spilsbury (2013) dalam penelitiannya mengatakan bahwa pengasuhan oleh orangtua pengganti (grandparents) tidak selamanya memiliki stigma negatif terhadap perkembangan anak, karena apabila kakek nenek mengasuh secara proporsional maka anakpun akan berkembang sebagaimana mestinya diantaranya aspek kemandirian dan kedisiplinan. Dimana, kakek dan nenek membangun hubungan yang baik dan harmonis dengan cucu-cunya, tanpa ada batas. Hal ini hubungan cucu dan kakeknenek digambarkan berdasarkan kepedulian kakek-nenek (grandparents) terhadap kebutuhan cucunya. Kakek-nenek (grandparents) memantau dan menyeimbangkan tingkat interaksi yang tepat dengan cucu mereka.

Berdasarkan penelitian sebelumnya yang dilakukan oleh Statham, (2011), terdapat beberapa dampak negatif terhadap anak yang diasuh oleh kakek dan neneknya. Dampak negatif tersebut diantaranya adalah pada proses belajar anak, yaitu kurangnya kemampuan anak pada persiapan sekolah 
mereka seperti pemahaman warna, huruf, angka dan sebagainya, anak mencari perhatian dari guru-gurunya dan temantemannya serta membuat kegaduhan dalam kelas. Artinya bahwat tidak adanya kehadiran kedua orangtua baik ayah maupun ibu, menjadikan anak tidak memiliki model utama dalam keluarga. Sehingga anak memperlihatkan perilaku mencari perhatian kepada guru-gurunya, teman-temannya, orangtua pengganti maupun orang lain.

Shakya, Usita, Eisenberg, Weston, \& Liles, (2012) menyatakan bahwa terdapat masalah-masalah yang dihadapi kakek dan nenek dalam mengasuh cucunya, mulai dari masalah di level intrapersonal hingga level masyarakat. Masalah tersebut diantaranya berkaitan dengan kesehatan dan usia kakek nenek, konflik pribadi yang sering muncul, kesulitan berinteraksi dengan sistem sekolah anak, dan lain sebagainya. Artinya bahwa anak yang di asuh oleh orangtua pengganti akan mengalami berbagai gangguan kesehatan fisik juga akan sulit berinteraksi dengan orang lain.

Selanjutnya Belleau, (2013) hasil penelitiannya bahwa apabila dibandingkan dengan anak-anak yang tinggal bersama orangtua, anak-anak yang tidak tinggal bersama orangtua cenderung mengalami masalah kesehatan fisik, menderita depresi, kecemasan dan gangguan psikoaktif lainnya. Mereka memiliki masalah perilaku sosial, kurang berhasil di sekolah, putus sekolah, serta memiliki masalah dalam bersosialisasi.

Senada dengan hasil penelitian yang dilakukan oleh Beazley, Butt, dan Ball (2018) bahwa anak-anak yang ditinggalkan oleh orangtua terjerat dalam kecemasan masyarakat, emosional terganggu (Malu, tidak percaya diri, tidak disiplin dan tidak sejahtera), anak-anak menjadi mudah putus asa, takut dan tidak mandiri dalam melakukan aktivitas. Dalam bersosialisasi anak menjadi mudah marah, dan tidak mampu mengendalikan emosional yang ada dalam diri.

Kemudian berkaitan dengan sikap anak, anak yang diasuh oleh kakek dan nenek cenderung suka membantah, suka berbohong dan pemalas. Namun, penelitian yang dilakukan oleh Tan, Buchanan, \& Griggs, (2009) justru membuktikan bahwa terdapat peran positif dari pengasuhan oleh kakek dan nenek bagi anak yang ditinggalkan oleh orangtua demi sebuah pekerjaan. Peran positif tersebut berkaitan dengan penyesuaian diri anak di kalangan remaja atau pertemanannya. Selain itu, Statham, (2011) dalam hasil penelitiannya juga memaparkan bahwa terdapat dampak positif yang timbul dari pengasuhan kakek dan nenek yaitu beberapa tahun sejak kecil anak memiliki kosa kata yang lebih baik. Dampak-damapak yang terjadi disebabkan oleh berbagai alasan seperti kakek dan nenek memiliki akses yang rendah untuk mengatur anak ketika bersama dengan kelompok bermainnya. Artinya bahwa anak dari orangtua merantau memiliki kognitif yang baik, sikap keberanian dalam menyelesaikan konflik dengan temannya, bertanggung jawab atas diri sendiri dan mandiri dalam mengerjakan tugastugasnya, serta sudah bisa mengenal terkait waktu bermain, waktu istirahat, dan waktu belajar.

Penelitian oleh Gottzén \& Sandberg (2017), hasilnya bahwa anak-anak merasa bahagia ketika kakek-nenek peduli dan memberikan respon positif ketika mereka ditinggalkan orangtua. Kakek-nenek menciptakan lingkungan yang nyaman bagi anak. Artinya bahwa pengasuhan oleh kakek-nenek (grandparents) memberikan nilai yang secara umum, yaitu kekeluargaan, cinta kasih, kenyamanan, kebaikan dan perawatan yang menyenangkan. Dalam hal ini pengasuhan yang dilakukan oleh kakek- nenek 
$542 \mid$ Kemandirian dan Kedisplinan Anak yang Diasuh Oleh Orangtua Pengganti

(grandparents) justru mampu membentuk kemandirian dan kedisiplinan anak yang baik yaitu terlihat pada perilaku anak dalam kesehariannya di rumah seperti anak mengerjakan pekerjaan rumah sendiri tanpa ada pendampingan orangtua pengganti, anak mandi dan ganti pakaian sendiri, dan anak kesekolah sendiri tanpa di antar oleh orangtua pengganti.

Khususnya subyek pada penelitian ini, menunjukkan adanya sikap mandiri dan disiplin yang sangat baik selama diasuh oleh orangtua pengganti. Subyek SR memiliki sikap mandiri dan disiplin yang baik, dimana SR selalu melakukan pekerjaan rumah dengan baik tanpa bersandar pada orangtua pengganti. SR kesekolah sendiri, mandi dan makan sendiri, ganti pakaian dan pakai sepatu sendiri. Setiap bangun pagi, SR tidak merepotkan orangtua pengganti, SR bangun pagi berdoa, dan merapikan tempat tidurnya sendiri. Berbeda dengan penelitian sebelumnya, yang menyatakan bahwa ketidakhadiran orangtua akan berdampak negatif pada anak. Namun, dalam penelitian ini, selain dampak negatif yang terlihat pada perkembangan anak, pengasuhan oleh orangtua pengganti juga memiliki dampak positif pada perkembangan anak.

Oleh karena itu, penelitian ini bertujuan untuk melihat mendeskripsikan secara keseluruhan mengenai bagaimana pengasuhan orangtua pengganti, bentukbentuk pengasuhan anak usia 4-6 tahun yang dilakukan oleh orangtua pengganti, faktor-faktor yang mempengaruhi dampak pengasuhan anak oleh orangtua pengganti, dampak pengasuhan orangtua pengganti terhadap kemandirian dan kedisiplinan anak usia 4-6 tahun, dan strategi orangtua pengganti dalam menanamkan kemandirian dan kedisplinan pada diri anak.

\section{METODOLOGI}

Penelitian ini dilaksanakan di rumah orangtua pengganti di kampung Hobobelu Desa Ekoroka Kecamatan Golewa Kabupaten Ngada. Penelitian ini adalah penelitian kualitatif dengan pendekatan studi kasus. Pendekatan kulitatif digunakan untuk memperoleh informasi terperinci tentang bagaimana kemandirian dan kedisplinan anak yang diasuh oleh orangtua pengganti (grandparents).

Metode penelitian yang digunakan dalam penelitian ini adalah studi kasus. Tujuan utama untuk mendapatkan gambaran pola pengasuhan orangtua pengganti (grandparents) dalam dalam menanamkan sikap mandiri dan disiplin kepada anak dengan memberikan peraturan, nasihat, dan hukuman maupun penghargaan kepada anak. Penelitian dilaksanakan di kediaman orangtua pengganti di Kabupaten Ngada. Fokus penelitian ini adalah kemandirian dan kedisplinan anak yang diasuh oleh orangtua pengganti.

Peneliti mengamati perilaku anak dirumah. Selain itu, peneliti mengamati pengasuhan kakek dan nenek selaku orangtua pengganti dalam menerapkan peraturan, memberikan hukuman, nasihat untuk mengurangi perilaku salah dan memberikan reward pengahargaan untuk mempertahankan perilaku benar, serta peran kakek dan nenek dalam menerapkan sikap mandiri dan teknik disiplin pada anak. Peneliti juga mengamati faktor-faktor yang mempengaruhi pola asuh orangtua pengganti terhadap kemandirian anak, serta karakteristik budaya pola asuh budaya setempat.

Observasi dilakukan langsung oleh peneliti serta juga terlibat langsung dalam kegiatan-kegiatan yang dilakukan oleh sumber data dengan menggunakan pedoman observasi 
Wawancara yang dilakukan dalam penelitian ini adalah wawancara tak terstruktur. Wawancara dilakukan kepada pihak-pihak yang mampu memberikan data sesuai dengan masalah yang diteliti.

Tahap penelitian kualitatif dengan pendekatan studi kasus menggunakan model dan proses penelitian menurut Campbell. Cara analisis penjodohan Campbell ditujukan untuk mencapai konseptual dalam pemetaan konsep hasil lapangan. Pertama, data dan informan menghasilkan serangkaian pernyataan, informasi yang diperoleh dari informan menggambarkan konsep. Kedua, informasi yang didapatkan dihubungkan dengan pernyataan yang serupa sehingga pengelompokkan pernyataan memiliki keterkaitan dengan fokus penelitian yang digambarkan melalui peta konsep. Peta konsep ini membantu peneliti untuk menggabungkan dan membangun konseptual materi.

\section{HASIL DAN PEMBAHASAN}

Berdasarkan temuan di lapangan bahwa orangtua pengganti yang mengasuh anak yang orangtuanya bekerja diluar negeri adalah kakek dan neneknya sendiri. Kakek dan nenek memiliki peran dalam memberikan dukungan ekonomi dan emosional. Kakek dan nenek menjadi fungsi utama keluarga sebagai sarana memberikan pengalaman untuk interaksi sosial bagi anak. Interaksi yang mendalam, mengasuh dan berusaha memberikan rasa nyaman bagi cucu. Kakek dan nenek yang pekerjaan hanya sebagai seorang petani harus bekerja keras juga mengasuh anak cucunya.

Dalam mendidik perilaku anak, orangtua pengganti juga memberikan ketentuan berupa hadiah dan hukuman bagi cucunya. Jika cucu melakukan sebuah pekerjaan dengan baik, membantu neneknya cuci piring, menaati perintah kakek dan neneknya, bangun pagi tanpa dibangunin, kakek dan nenek akan memberikan hadiah berupa pujian, kadang membelikan barang mainanya, agar anak ini merasa diperhatikan oleh mereka. Jika anak berbuat salah, maka kakek dan nenek akan memberikan hukuman yang ringan yaitu dengan menjewer telinganya sebagai teguran kepada anak bahwa apa yang dilakukan itu keliru.

Tabel 1. Bentuk Pengasuhan Orangtua Pengganti

\begin{tabular}{|c|c|}
\hline $\begin{array}{c}\text { Bentuk } \\
\text { Pengasuhan }\end{array}$ & $\begin{array}{l}\text { Hasil } \\
\text { Deskripsi pengasuhan } \\
\text { Orangtua Pengganti }\end{array}$ \\
\hline Demokratis & $\begin{array}{l}\text { Kakek dan nenek tidak memaksa } \\
\text { cucu, untuk melakukan aktivitas } \\
\text { sesuai kehendak mereka, namun } \\
\text { selalu mengingatkan cucu untuk } \\
\text { displin waktu. Hal ini penting, } \\
\text { karena untuk melatih dan } \\
\text { membentuk karakter anak } \\
\text { dikemudian hari. }\end{array}$ \\
\hline Autoritatif & $\begin{array}{l}\text { Membiarkan cucu melakukan } \\
\text { aktivitas ringan sendiri, seperti } \\
\text { memakai baju, mandi, memakai } \\
\text { sepatu sendiri }\end{array}$ \\
\hline 1019 & orangtua \\
\hline
\end{tabular}
memiliki dampak yang sangat besar terhadap perkembangan tingkah laku anak, karena orangtua dengan model pola asuh otoriter akan cenderung menghasilkan anak dengan ciri kurang matang, kurang kreatif dan inisiatif, tidak tegas dalam menentukan baik buruk, benar salah, suka menyendiri, kurang supel dalam pergaulan, ragu-ragu dalam bertindak atau mengambil keputusan karena takut dimarahi. Sementara anak yang diasuh dengan pola permisif menunjukkan gejala cenderung terlalu bebas dan sering tidak mengindahkan aturan, kurang rajin beribadah, cenderung tidak sopan, bersifat agresif, sering mengganggu orang lain, sulit diajak bekerjasama, sulit menyesuaikan diri dan emosi kurang stabil. Sedangkan anak yang diasuh dengan pola demokratis menunjukkan kematangan jiwa yang baik, emosi stabil, memiliki rasa tanggungjawab 
544 | Kemandirian dan Kedisplinan Anak yang Diasuh Oleh Orangtua Pengganti

yang besar, mudah bekerjasama dengan orang lain, mudah menerima saran dari orang lain, mudah diatur dan taat pada peraturan atas kesadaran sendiri (Dwiyanti, 2013).

Walaupun orangtua pengganti adalah kakek dan nenek namun tetap mengasuh anak dengan baik, mereka menganggap cucu mereka seperti anak mereka, sehingga dalam proses pengasuhan kebutuhan pokok anak, dipenuhi dan diperhatikan dengan baik. Kakek dan nenek selalu mengajarkan cucunya tentang keteladanan, salah satunya yaitu tentang bagaimana belajar sopan santun melalui tutur kata dan bahasa yang sopan. Kakek dan nenek menerapkan bahasa yang sopan karena itu sebuah tanda untuk mematuhi orang yang lebih tua dan agar dapat berperilaku baik di dalam lingkungan keluarga dan lingkungan masyarakat.

Selain itu kakek dan nenek menyatakan bahwa mereka mendidik cucunya dengan pembiasaan, melalui tingkah laku, keterampilan, dan kecakapan, tertentu salah satunya dalam hal menata baju,dan sepatu. Kakek dan nenek samasama juga menanamkan tanggungjawab melalui pembinaan perhatian dalam bentuk akhlak, dan spiritual. Kakek dan nenek selalu khawatir dan gelisah jika cucunya belum juga pulang. Apalagi neneknya, pasti menyusul untuk menjemput cucunya, pulang ke rumah.

Ketika waktu berdoa nenek selalu mengingatkan cucunya untuk berdoa bersama dan ini merupakan bekal spiritual bagi sang cucu juga mengajarkan tentang arti terimakasih yang kaitannya dengan perilaku sang cucu, ketika di masakin apa adanya, dan ketika di kasih uang saku paspasan harus mengucap syukur pada Tuhan. Nilai-nilai ini tentu sangat bermanfaat untuk sang cucu, agar sang cucu dapat tumbuh dengan pribadi yang baik.
Tabel 2. faktor-faktor yang mempengaruhi pengasuhan anak oleh orangtua pengganti

\begin{tabular}{|c|c|}
\hline & \\
\hline Faktor & Deskripsi faktor \\
\hline $\begin{array}{ll}\text { Situasi dan } \\
\text { kondisi } \\
\text { ekonomi } \\
\text { keluarga }\end{array}$ & $\begin{array}{l}\text { 1. Tuntuan ekonomi } \\
\text { membuat orangtua anak } \\
\text { pergi bekerja di luar } \\
\text { negeri demi memenuhi } \\
\text { segala kebutuhan anak dan } \\
\text { keluarga. } \\
\text { 2. Orangtua pengganti } \\
\text { adalah kakek dan nenek } \\
\text { dengan keadaan yang } \\
\text { terbatas harus bekerja } \\
\text { mengasuh, merawat anak } \\
\text { cucu. } \\
\text { 3. Kakek dan nenek yang } \\
\text { hidup sederhana bekerja } \\
\text { demi memenuhi } \\
\text { kebutuhan cucu mereka. } \\
\text { Mereka mengaanggap } \\
\text { cucu seperti anak kandung } \\
\text { sehingga apa yang } \\
\text { menjadi kebutuhan harian } \\
\text { cucu adalah } \\
\text { tanggungjawab kakek dan } \\
\text { nenek. }\end{array}$ \\
\hline $\begin{array}{l}\text { Kondisi fisik } \\
\text { dan keadaan } \\
\text { emosional } \\
\text { orangtua } \\
\text { pengganti }\end{array}$ & $\begin{array}{l}\text { 1. Nenek sering mengalami } \\
\text { sakit pada bagian } \\
\text { punggung sehingga nenek } \\
\text { kadang tidak bekerja } \\
\text { 2. Usia yang semakin tua } \\
\text { membuat keadan } \\
\text { emosional kakek dan } \\
\text { nenek tidak stabil yang } \\
\text { membuat kakek dan nenek } \\
\text { kadang bersikap marah } \\
\text { dan tegas pada cucu } \\
\text { mereka }\end{array}$ \\
\hline
\end{tabular}

Pola asuh yang diterapkan oleh orangtua pengganti tidak lepas dari pengaruh nilai dalam budaya tertentu terutama budaya lokal tempat menetapnya keluarga. Menurut mereka, bahwa dengan menerapkan budaya dan nilai setempat dapat meningkatkan keberhasilan anak.. Pola asuh yang diterapkan oleh orangtua juga tidak lepas dari pengaruh nilai dalam budaya tertentu terutama budaya lokal tempat menetapnya sebuah keluarga (Kotchick \& Forehand, 2002). Santrock 
juga mengatakan hal yang sama bahwa pengasuhan dapat dipengaruhi budaya, etnisitas, dan status sosial ekonomi. Budaya memiliki nilai-nilai yang digunakan sebagai tolok ukur yang menentukan baik-buruk, boleh-tidak boleh, benar-salah dalam ekspresi perilaku anak (Fitria, 2016).

Tabel 3. Pola asuh budaya setempat

\begin{tabular}{llr}
\hline \multicolumn{1}{c}{ Faktor } & \multicolumn{2}{c}{ Deskil } \\
\hline Pola asuh & Masayarakat di di & Kampung \\
budaya & Hobobelu Desa & Ekoroka \\
setempat & merupakan warga & yang \\
& datang dari kampung & Belu \\
& dan menetap di Desa \\
& Ekoroka. Orangtua dari Desa \\
& Ekoroka pada umumnya, \\
& mengaku mendidik anak \\
& dengan keras dan tegas. \\
& Tegas disini bukan \\
& mengekang ruang gerak anak \\
& namun mendidik dan \\
& mengajar anak agar mandiri \\
& dan disiplin. Hal ini \\
& menyebabkan & interaksi \\
& dengan cucu kadang tidak \\
& efektif. & \\
\hline
\end{tabular}

Budaya juga mempengaruhi tingkah laku anak. Apalagi budaya ngada yang memiliki berbagai ritual adat di dalamnya terkandung makna dan nilai bagi kehidupan anak. Seringkali orang tua mengikuti caracara dan kebiasaan-kebiasaan masyarakat setempat dalam mengasuh anak, karena pola-pola tersebut dianggap berhasil dalam mendidik anak kearah kematangan (Rahman \& Yusuf, 2012).

\section{KESIMPULAN}

Peran pengasuhan yang orangtua berikan adalah kepada kakek dan nenek yang berperan sebagai orangtua pengganti. Orangtua pengganti adalah orang yang dipercayakan dan di anggap mampu oleh orangtua dalam menjaga, merawat dan mengasuh anak. Bentuk pengasuhan yang diberikan oleh orangtua pengganti adalah pengasuhan yang bersifat fleksibel dan dalam kontol orangtua kandung. Keterlibatan control orangtua adalah untuk mengontrol orangtua pengganti bagaimana kebutuhan pokok anak. Bentuk pengasuhan yang diberikan adalah secara demokratis dan otoritatif Pola asuh yang diterapkan oleh orangtua pengganti tidak lepas dari pengaruh nilai dalam budaya tertentu terutama budaya lokal tempat menetapnya keluarga. Dapat disimpulkan bahwa pola pengasuhan orangtua pengganti juga mempengaruhi kemandirian dan kedisiplinan anak. Pengasuhan yang baik akan berdampak pada sikap dan perilaku anak. Pengasuhan orangtua pengganti tidak selamanya memberikan stigma yang negative seperti yang tertuang pada hasil penelitian terdahulu. Anak yang diasuh oleh orangtua pengganti juga bisa hidup mandiri dan disiplin juga mampu berkompetensi dengan anak-anak yang tinggal bersama kedua orangtuanya.

\section{UCAPAN TERIMA KASIH}

Penulis menyampaikan ucapan terima kasih kepada kakek dan nenek selaku orangtua pengganti subyek, yang telah memberi persetujuan dan telah membantu peneliti selama proses pengumpulan data. Penulis juga mengucapkan terima kasih kepada dosen pembimbing yang sudah membantu peneliti dalam menyempurnakan hasil penelitian ini. Ucapan terima kasih juga kepada tim editor jurnal Obsesi yang telah memberikan saran, kritik dan rekomendasi untuk perbaikan artikel ini.

\section{DAFTAR PUSTAKA}

Alberto, A., Cuervo, V., \& Nieblas, C. A. (2018). CR. Children and Youth Services Review, \#pagerange\#. 
546 | Kemandirian dan Kedisplinan Anak yang Diasuh Oleh Orangtua Pengganti

https://doi.org/10.1016/j.childyouth.2 018.10 .015

Beazley, H., Butt, L., \& Ball, J. (2018). "Like it, don"t like it, you have to like it': children's emotional responses to the absence of transnational migrant parents in Lombok, Indonesia. Children's Geographies, 16(6), 591603.

https://doi.org/10.1080/14733285.201 7.1407405

Belleau, L. (2013). The Impact of Parental Separation on Young Children's Mental Health, 6(September).

Breheny, M., Stephens, C., \& Spilsbury, L. (2013). Involvement without interference: How grandparents negotiate intergenerational expectations in relationships with grandchildren. Journal of Family Studies, 19(2), 174-184. https://doi.org/10.5172/jfs.2013.19.2. 174

Coore Desai, C., Reece, J. A., \& Shakespeare-Pellington, S. (2017). The prevention of violence in childhood through parenting programmes: a global review. Psychology, Health and Medicine, 22, 166-186.

https://doi.org/10.1080/13548506.201 6.1271952

Edwards, O. W. (2018). School perceptions of children raised by grandparents. Journal of Applied School Psychology, 34(1), 86-100. https://doi.org/10.1080/15377903.201 7.1403401

Fitria, N. (2016). Pola Asuh Orang Tua Dalam Mendidik Anak Usia Prasekolah Ditinjau Dari Aspek Budaya Lampung. Jurnal Fokus Konseling, 2(2), 99-115. https://doi.org/32536457784

Froiland, J. M. (2013). Parents 'Weekly Descriptions of Autonomy Supportive
Communication : Promoting Children 's Motivation to Learn and Positive Emotions.

https://doi.org/10.1007/s10826-0139819-x

Gottzén, L., \& Sandberg, L. (2017). Creating safe atmospheres? Children's experiences of grandparents' affective and spatial responses to domestic violence. Children's Geographies, 3285, 1-13. https://doi.org/10.1080/14733285.201 7.1406896

Hasbullah. (2012). dasar-dasar ilmu pendidikan. Jakarta: PT.RajaGrfindo Persada.

Hasnida. (2015). Analisis Kebutuhan Anak Usia Dini. Jakarta: Luxima.

John W.Santrock. (2011). Perkembangan Anak. (T. S. G. B, Ed.) (7 Jilid 2). Jakarta: Erlangga.

Kasmadi. (2013). Membangun Soft Skill Anak-anak Hebat. Bandung: Alfabeta.

Margaretha, L., Kurniah, N., Dharmayana, I. W., Sasongko, R. N., \& Lutfi, M. (2018). The Influence of Parents , Parenting Style towards the Independence of Preschool Children, 11(August).

https://doi.org/10.17485/ijst/2018/v11 i29/128245

Nova Ardy Wiyani. (2012). Bina Karakter Anak Usia Dini: Panduan Orang Tua dan Guru dalam Membentuk Kemandirian dan Kedisiplinan Anak Usia Dini. Yogyakarta: AR-RUZZ MEDIA.

Shakya, H. B., Usita, P. M., Eisenberg, C., Weston, J., \& Liles, S. (2011). Journal of Gerontological Social Work Family Well-Being Concerns of Grandparents in Skipped Generation Families Family WellBeing Concerns of Grandparents, (August 2013), 37-41. https://doi.org/10.1080/01634372.201 


\subsection{2}

Sherr, L., Roberts, K. J., Hothi, S., \& Balchin, N. (2018). Never too old to learn - Parenting interventions for grandparents-A systematic review. Cogent Social Sciences, 4(1), 1-22. https://doi.org/10.1080/23311886.201 8.1508627

Statham, J. (2011). Grandparents providing child care Briefing Paper, (10).

Suparmi, S., Ekowarni, E., Adiyanti, M., \& Helmi, A. F. (2018). Pengasuhan sebagai Mediator Nilai Anak dalam memengaruhi Kemandirian Anak dengan Down Syndrom. Jurnal Psikologi, $\quad 45(2), \quad 141$. https://doi.org/10.22146/jpsi.34716

Tan, J., Buchanan, A., \& Griggs, J. (2009). Grandparenting and Adolescent Adjustment in Two-Parent Biological 23(1), $\quad$ 67-75. https://doi.org/10.1037/a0014383

Tegariyani, S., \& Santoso, P. (2018). Mom Worked: Patterns of Parenting and Attachment by Children, 244(Ecpe), 189-192.

Yuliani Nurani Sujiono. (2009). Konsep Dasar Pendidikan Anak Usia Dini. Jakarta: PT Macana Jaya Cermelang,. 